\title{
KETENTUAN HUKUM TINDAK PIDANA PENCABULAN TERHADAP ANAK DIBAWAH UMUR MENURUT UNDANG UNDANG PERLINDUNGAN ANAK
}

\author{
Oleh : Ony Rosifany
}

Dosen Fakultas Hukum Universitas 17 Agustus 1945 Samarinda

\begin{abstract}
One of the triggers for the crime of sexual immorality in this case is the rapid development of information and technology flows. Fornication is an act carried out by someone who is motivated by sexual desire to do things that can arouse lust, thereby causing self-satisfaction. What is troubling society is the criminal act of child sexual abuse, whether it is a boy or a girl. Fornication is an act committed by someone who is motivated by sexual desire.

In general, the factors that cause the crime of child sexual immorality can be caused by internal factors as well as external factors.

The legal provisions for the crime of child molestation against children are contained in Law Number 35 of 2014 concerning Amendments to Law Number 23 of 2002 concerning Child Protection, stated in Article 76 E and Article 82.
\end{abstract}

\section{Keywords: Crime, Fornication, Children}

\begin{abstract}
ABSTRAK
Salah satu pemicu terjadinya tindak pidana pencabulan dalam hal ini salah karena pesatnya perkembangan arus informasi dan teknologi. Pencabulan merupakan tindakan yang dilakukan seseorang yang didorong oleh keinginan seksual untuk melakukan hal-hal yang dapat membangkitkan hawa nafsu birahi, sehingga menimbulkan kepuasan pada dirinya. Yang meresahkan masyarakat adalah tindak pidana pencabulan anak, apakah itu anak laki-laki ataupun anak perempuan. Pencabulan merupakan tindakan yang dilakukan oleh seseorang yang terdorong keinginan seksual.

Faktor yang menyebabkan terjadinya tindak pidana pencabulan anak dibawah umur secara umum dapat disebab oleh faktor dalam diri sepelaku tindak pidana pencabulan maupun faktor penyebab dari luar (ekstern).

Ketentuan hukum tindak pidana pencabulan anak terhadap anak yang
\end{abstract}


tertuang dalam Undang-Undang Nomor 35 Tahun 2014 tentang Perubahan atas Undang-Undang Nomor Nomor 23 tahun 2002 tentang Perlindungan Anak, disebutkan dalam Pasal 76 E dan Pasal 82.

\section{Kata Kunci : Tindak Pidana, Pencabulan, Anak}

\section{PENDAHULUAN}

\section{A. Latar Belakang}

Negara bertujuan melindungi segenap bangsa Indonesia dan seluruh tumpah darah Indonesia, memajukan kesejahteraan umum, mencerdaskan kehidupan bangsa, ikut serta dalam upaa perdamaian dunia berdasarkan kemerdekaan, perdamaian abadi dan keadilan sosial hal ini merupakan tujuan Bangsa Indonesia sebagaimana tertuang dalam Pembukaan UndangUndang Dasar Negara Republik Indonesia.

Permasalahan hukum marak terjadi di masyarakat seiring dengan perkembangan zaman, ilmu pengetahuan dan teknologi yang semakin pesat. Kejahatan merupakan salah satu kenyataan dalam kehidupan yang memerlukan penanganan secara khusus. Upaya untuk menanggulangi kejahatan tersebut telah dilakukan meskipun dalam kenyataan sangat sulit untuk memberantas kejahatan secara tuntas karena pada dasarnya kejahatan selalu berkembang seiring dengan perkembangan masyarakat, tentunya permasalahan hukum ikut berkembang seiring dengan perkembangan permasalahan yang terjadi dimasyarakat. Salah satu pemicu terjadinya tindak pidana pencabulan dalam hal ini salah karena pesatnya perkembangan arus informasi dan teknologi. Pencabulan merupakan tindakan yang dilakukan seseorang yang didorong oleh keinginan seksual untuk melakukan hal-hal yang dapat membangkitkan hawa nafsubirahi, sehingga menimbulkan kepuasan pada dirinya.

Salah satu tindak pidana yang meresahkan masyarakat adalah tindak pidana pencabulan anak, apakah itu anak laki-laki ataupun anak perempuan. Pencabulan merupakan tindakan yang dilakukan oleh seseorang yang terdorong keinginan seksual. Dalam kasus pencabulan anak dibawah umur, bahwa pelaku pencabulan tidak lagi mengenal status, pangkat, pendidikan, jabatan dan usia korbannya.

Perlindungan anak bertujuan untuk menjamin terpenuhinya hak-hak anak agar dapat hidup, tumbuh, berkembang dan berpartisipasi secara optimal sesuai dengan harkat dan martabat kemanusiaan serta mendapat perlindungan dari kekerasan dan diskriminasi demi terwujudnya anak Indonesia yang berkualitas, berakhlak mulia dan sejahtera. Hal ini jelas tertuang dalam Pasal 3 Undang-Undang Nomor 23 Tahun 2002 tentang 
Perlindungan Anak.

Pelaku tindak pidana pencabulan terhadap anak merasa bahwa anak-anak dapat menjadi salah satu sasaran untuk menyalurkan hasrat seksualnya. Hal ini karena dipengaruhi oleh pendapat bahwa anak-anak diangap tidak cukup mampu untuk mengerti bahwa perbuatan tersebut merupakan tindak pidana atau bahkan anak-anak tidak mempunyai keberanian untuk menolak keinginan pelaku karena adanya ancaman atau iming-iming akan diberikan hadiah. Korban anak pencabulan tentunya akan berdampak pada perkembangan jiwa anak atau dampak spikologi pada anak.

Dampak spikologis pada anak akan melahirkan trauma yang berkepanjangan yang kemudian akan melahirkan sikap tidak sehat seperti misalnya minder, takut yang berlebihan, perkembangan jiwa anak terganngu dan akhirnya berakibat pada keterbelakangan mental. Hal ini menjadi kenangan buruk bagi anak korban pencabulan. Kasus kekerasan terhadap anak yang terjadi di Indonesia sebagai salah satu indikator buruknya kualitas perlindungan terhadap anak, keberadaan anak yang dianggap belum mampu untuk hidup mandiri tentunya hal tersebut sangat membutuhkan orang dewasa sebagai pelindunganya. Diharapkan setiap anak mempu memikul tangung jawab hal ini diharapkan agar anak perlu mendapatkan kesempatan yang seluas-luasnya untuk tumbuh dan berkembang secara optimal baik fisik, mental maupun sosial dan berakhlak mulia. Sehingga perlunya dilakukan upaya perlindungan untuk mewujudkan kesejahteraan anak dengan memberikan jaminan terhadap pemenuhan hak-haknya serta adanya perlakukan tanpa diskriminasi.

Sudah sepatutnya aparat penegak hukum memberikan sanski yang tegas tehadap pelaku tindak pidana pencabulan terhadap anak. Hal ini agar dapat memberikan efek jera bagi pelaku tindak pidana pencabulan terhadap anak.

\section{B. Rumusan Masalah}

1. Apa yang menjadi aktor penyebab seseorang melakukan tindak pidana pencabulan terhadap anak?

2. Apa sanski hukumnya terhadap pelaku tindak pidana pencabulan terhadap anak menurut ketentuan Undang-Undang Perlindungan Anak? 


\section{KERANGKA DASAR TEORI}

\section{A. Pengertian Tindak Pidana}

Istilah tindak pidana berasal dari istilah yang dikenal dalam hukum Belanda yaitu strafbaar feit, yang terdiri dari tiga kata, yakni straf, baar dan feit. Straf diterjemahkan dengan pidana dan hukum. Baar diterjemahkan dengan dapat dan boleh. Dan untuk kata feit, diterjemahkan dengan tindak, peristiwa, pelanggaran dan pembuatan. Jadi istilah strafbaar feit adalah peristiwa yang dapat dipidana. Sedangkan delik dalam bahasa asing disebut delict yang artinya suatu perbuatan yang pelakunya dapat dikenakan hukuman pidana.

Tindak pidana merupakan suatu pengertian dasar dalam hukum pidana. Tindak pidana adalah suatu pengertian yuridis, lain halnya dengan istilah "perbuatan jahat" atau kejahatan yang bisa diartikan secara yuridis (hukum) atau secara kriminologi.

Tindak Pidana juga diartikan sebagai suatu dasar pokok dalam menjatuhi pidana pada orang yang telah melakukan perbuatan pidana atas dasar pertanggungjawaban seseorang atas perbuatan yang telah dilakukannya, tapi sebelum itu mengenai dilarang dan diancamnya suatu perbuatan yaitu mengenai perbuatan pidana sendiri, yaitu berdasarkan atas asas legalitas (principle of legality), asas yang menentukan bahwa tindak pidana ada perbuatan yang dilarang dan diancam dengan pidana jika tidak ditentukan terlebih dahulu dalam undang-undang. ${ }^{2}$

Istilah tindak pidana selain strafbaar feit dipakai juga istilah lain yang berasal dari bahasa latin yakni delictum. Dalam bahasa Jerman disebut delict, dalam bahasa Prancis disebut delit. Dan dalam Bahasa Indonesia dipakai istilah delik. Dimana dalam kamus Bahasa Indonesia sebagaimana dikutif Leden Marpaung "Delik merupakan perbuatan yang dapat dikenakan hukuman karena merupakan pelanggaran terhadap undang-undang tindak pidana". ${ }^{3}$

Beberapa pendapat mengenai Strafbaar Feit, yakni :

1. Moeljatno, mengatakan bahwa strafbaar feit adalah suatu perbuatan yang dilarang oleh suatu aturan hukum, dimana larangan tersebut disertai suatu ancaman (sanki) yang berupa pemidanaan bagi siapa yang melanggar larangan tersebut atau dapat juga dirumuskan bahwa perbuatan pidana adalah perbuatan yang oleh suatu aturan hukum

\footnotetext{
1 Amir Ilyas, 2012, Asas-asas Hukum Pidana, Penerbit Rangkang Education Yogyakarta, Yogyakarta. Hal. 19

${ }^{2}$ Ibid. Hal. 27

${ }^{3}$ Laden Marpaung, 2008, Asas-asas-Praktik Hukum Pidana, Penerbit Sinar Grafika, Jakarta, Hal. 7
} 
dilarang dan diancam pidana. ${ }^{4}$

2. Wirjono Prodjidikoro, mengatakan bahwa strafbaar feit adalah suatu perbuatan yang pelakunya dapat dikenakan hukuman pidana. ${ }^{5}$

3. Roeslan Saleh, bahwa setiap perbuatan oleh masyarakat dirasakan sebagai perbuatan yang tidak atau tidak dapat dilakukan sehingga adanya penekanan pada perasaan hukum masyarakat oleh karena itu, sesuatu perbuatan pidana berarti perbuatan yang menghambat atau bertentangan dengan tercapainya tatanan dalam pergaulan yang dicita-citakan masyarakat. ${ }^{6}$

\section{B. Pengertian Tindak Pidana Pencabulan}

Perbuatan cabul (ontuchtige hendelingen) adalah segala macam wujud perbuatan, baik yang dilakukan pada diri sendiri maupun dilakukan pada orang lain mengenai dan yang berhubungan dengan alat kelamin atau bagian tubuh lainnya yang dapat merangsang nafsu seksual. Misalnya mengelus-elus atau menggosok-gosok penis atau vagina, memegang buah dada, mencium mulut seseorang dan sebagainya ${ }^{7}$. Sedangkan dalam kamus bahasa Indonesis, istilah pencabulan berasal dari kata cabul yang diartikan sebagai "tindak senonoh, melanggar adat dan kesusilaan, melanggar kesopanan, keji dan kotor" ${ }^{8}$. Yang dimaksud dengan Perbuatan cabul" ialah segala perbuatan yang melanggar kesusilaan dan perbuatan keji yang berhubungan dengan nafsu kekelaminan, misalnya bercium-ciuman, meraba-raba anggota kemaluan, meraba-raba buah dada dan sebagainya. Persetubuhan termasuk juga dalam pengertian ini, tetapi dalam undang-undang hukum pidana disebutkan tersendiri.

Pencabulan merupakan kejahatan yang menyerang kehormatan, kesusilaan dan bertentangan dengan moral dan agama. Di karenakan perbuatan pencabulan perupakan pelanggaran hak asasi manusia yang kerap kali terjadi dan tidak ada alasan pembenarannya.

Bentuk pencabulan cukup beragam, ada beberapa jenis istilah tentang pencabulan, yaitu :

a) Exhition seksual, sengaja memamerkan alat kelamin pada anak.

b) Voyeurism, orang dewasa mencium anak dengan nafsu.

\footnotetext{
${ }^{4}$ P.A.F Lamintang, 1997, Dasar-dasar Hukum Pidana Indonesia, Penerbit Citra Aditya Bakti, Bandung, Hal. 72

${ }^{5}$ Wirjono Projodikoro, 1981, Asas-asas Hukum Pidana di Indonesia, Cet. Ke III, penerbit Eresco, Bandung Hal. 50

${ }^{6}$ Teguh Prasetyo, 2015 Hukum Pidana, Cetakan ke -VI, Penerbit PT Raja Grafindo Persada, Jakarta, hal 4

${ }^{7}$ Adami Chazawi, 2007, Tindak Pidana Mengenai Kesopanan, Penerbit Rajawali Grafindo Persada, Jakarta, Hal. 80

${ }^{8}$ Yanti Yuniar, 2012, Kamus Lengkap Bahasa Indonesia, Penerbit Agung Mulia, Jakarta.Hal. 12
} 
c) Fondling, mengelus/meraba alat kelamin anak.

d) Fellato, orang dewasa memaksa anak untuk melakukan kontak mulut.

Pelaku pencabulan terhadap anak-anak dibawah umur yang dapat juga disebut dengan child molester, dapat digolongkan ke dalam lima kategori, yaitu :

1. Immature, para pelaku melakukan pencabulan disebabkan oleh ketidakmampuan mengidentifikasi diri mereka dengan peran seksual sebagai orang tua.

2. Frustated, para pelaku melakukan kejahatannya (pencabulan) sebagai reaksi melawan frustasi seksual yang sifatnya emosional terhadap orang dewasa. Sering terjadi mereka beralih kepada anak-anak mereka sendiri (incest) merasa tidak seimbang dengan istrinya.

3. Sociopathic, para pelaku pencabulan yang melakukan perbuatannya dengan orang yang sama sekali asing baginya, suatu tindakan yang keluar dari kecendruangan agresif yang terkadang muncul.

4. Pathological, para pelaku pencabulan yang tidak mampu mengontrol dorongan seksual sebagai hasil psikosis, lemah mental, kelemahan organ tubuh atau kemerosotan sebelum waktunya (premature senile derioration).

Tindak pidana pencabulan termasuk dalam tindak pidana aduan. Tindak pidana aduan adalah tindak pidana yang penuntutannya berdasarkan adanya laporan dari pihak korban. ${ }^{9}$

\section{Pengertian Anak}

Anak (jamak: anak-anak) adalah seseorang lelaki atau perempuan yang belum dewasa atau belum mengalami masa pubertas. Anak juga merupakan keturunan kedua, dimana kata "anak" merujuk pada lawan dari orang tua, orang dewasa adalah anak dari orang tua mereka meskipun mereka telah dewasa. ${ }^{10}$

Pengertian anak menurut psikologi, anak adalah periode perkembangan yang merentang dari masa bayi hingga usia lima atau enam tahun, periode ini biasanya disebut periode prasekolah, kemudian berkembang setara dengan tahun sekolah dasar.

Anak-anak yaitu manusia muda dalam umur muda dalam jiwa dan perjalanan hidupnya karena mudah terpengaruh untuk keadaan sekitarnya. ${ }^{11}$

\footnotetext{
${ }^{9}$ Sudaryono dan Natangsa Subakti, 2005, Hukum Pidana, Penerbit Fakultas Hukum Muhamadiyah Surakarta, Surakarta. Hal. 131

${ }^{10}$ id.m.wikipedia.org, diakses tanggal 24 Januari 2020 jam 12.58 wita

${ }^{11}$ R.A. Koesnan, 2005, Susunan Pidana Dalam Negara Sosialis, Sumur, Bandung. Hal. 113
} 
Zakariya Ahmad Al Barry yang dimaksud dewasa adalah cukup umur untuk berketurunan dan muncul tanda laki-laki dewasa pada putra, muncul tanda-tanda wanita dewasa pada putri. Inilah dewasa yang wajar, yang biasanya belum ada sebelum anak putra berumur 12 tahun dan putri berumur 9 tahun. Kalau anak mengatakan bahwa ia dewasa, keterangannya dapat diterima karena ia sendiri yang mengalami. Kalau sudah melewati usia tersebut diatas tetapi belum nampak tanda-tanda yang menunjukkan bahwa ia telah dewasa, harus tunggu sampai ia berumur 15 tahun. ${ }^{12}$

Pengertian anak menurut Abintoro Prakoso, adalah mereka yang masih muda usia dan sedang berkembang, menentukan identitas, sehingga berakibat mudah terpangaruh lingkungan. ${ }^{13}$

Anak adalah amanah dan karunia dari Tuhan yang Maha Esa yang dalam dirinya melekat harkat dan martabat sebagai manusia seutuhnya. Anak merupakan makhluk sosial ini sama dengan orang dewasa. Anak tidak dapat tumbuh dan berkembang sendiri tanpa orang lain. Karena anak lahir dengan segala kelemahansehingga tanpa orang lain anak tidak mungkin dapat mencapai taraf kemanusia yang normal.

Pengertian anak menurut Pasal 1 Undang-Undang Nomor 4 Tahun 1974 tentang kesejahteraan anak menyebutkan bahwa "anak adalah mereka dibawah 18 tahun termasuk yang masih dalam kandungan". Pengertian anak menurut Undang-Undang Perlindungan Anak Nomor 23 Tahun 2002 Pasal 1 angka 1 menyebutkan, "anak adalah sesorang yang belum berusia 18 tahun, termasuk anak yang masih dalam kandungan".

Pengertian anak menurut Pasal 1 butir 5 Undang-Undang Nomor 39 Tahun 1999 tentang Hak Asasi Manusia menyebutkan bahwa : "anak adalah setiap manusia yang berusia di bawah 18 tahun dan belum menikah, termasuk anak yang masih dalam kandungan apabila hal tersebut demi kepentingannya".

Pengertian anak Undang-Undang Nomor 11 Tahun 2012 Tentang Sistem Peradilan Pidana Anak dalam Pasal 1 ayat (3) menjelaskan bahwa; "anak adalah anak yang telah berumur 12 tahun, tetapi belum berumur 18 tahun yang diduga melakukan tindak pidana.

Sedangkan Undang- Undang Hukum Perdata Buku 1 dalam Pasal 330 mengatur bahwa orang yang belum dewasa adalah mereka yang belum berumur 21 tahun, tetapi atau mereka yang belum berumur 21 tahun, tetapi telah menikah.

\footnotetext{
${ }^{12}$ Zakariya Ahmad Al Barry, 1993, Hukum Anak Dalam Islam, Bulan Bitang, Jakarta, Hal. 114

${ }^{13}$ Abintoro Prakoso, 2016, Hukum Perlindungan Anak, LaksBang PRESSindo, yogyakarta, Hal. 37
} 


\section{PEMBAHASAN}

\section{A. Faktor Penyebab seseorang melakukan tindak Pidana Pencabulan terhadap anak}

Secara umum faktor yang menyebabkan terjadinya tindak pidana pencabulan terhadap anak di bawah umur, dipengaruhi dua faktor, yaitu :

1. Faktor penyebab dari dalam (intern)

Faktor penyebab dari dalam diri pelaku sehingga ia melakukan perbuatan cabul, sebab dari dalam sulit dilihat secara langsung oleh orang dewasa, bahkan oleh penegak hukum sekalipun. Oleh karena itu dalam pemeriksaan dipengadilan diperlukan seorang ahli, yaitu seorang yang dalam dunia ilmu diakui mengetahui bidang kejiwaan manusia. Karena faktor penyebab dari dalam ini berkaitan dengan faktor kejiwaan dan faktor psikis. Faktor penyebab terjadinya pencabulan yang dilakukan terhadap anak ialah adanya perilaku seksual yang menyimpang yang dimiliki oleh sipelaku. Penyimpangan seksual yang ditempuh seseorang untuk mendapatkan kenikmatan seksual yang tidak sewajarnya, apalagi dalam kasus ini adalah pelaku mencabuli anak yang masih dibawah umur.

2. Faktor Penyebab dari luar (Ekstern)

Faktor penyebab yang berasal dari luar diri pelaku yang berpengaruh besar terhadap terjadinya perbuatan cabul terhadap anak dibawah umur adalah :

2.1. Faktor rendahnya pendidikan dan ekonomi

Rendahnya pendidikan formal dapat membuat seseorang mudah terpengaruh untuk melakukan suatu kejahatan tanpa memikirkan akibat dari perbuatannya. Pada kasus tindak pidana kesusilaan terutama pencabulan yang menjadi pelaku pada umumnya memiliki pendidikan formal yang sangat rendah tersebut para pelaku tidak berpikir bahwa dengan melakukan perbuatan tersebut dapat merugikan pelaku, dan mempermalukan keluarganya. Seseorang yang dalam lingkungan pendidikan yang baik akan mengisi hari-harinya dengan hal yang positif. Dikarenakan pendidikan yang rendah juga maka ia dapat mempengaruhi taraf ekonomi, dimana ekonomi juga menjadi salah satu penyebab seseorang melakukan suatu perbuatan yang melanggar norma hukum. Banyak ditemukan bahwa kebanyakan dari pelaku adalah mereka yang tidak mempunyai pekerjaan. Pendidikan yang dimaksud bukan hanya pendidikan formal dari sekolah akan tetapi pendidikan dalam arti pengetahuan umum lainnya khususnya di bidang hukum. 


\subsection{Faktor lingkungan keluarga}

Keluarga merupakan unit sosial terkecil dalam kehidupan bermasyarakat, bangsa dan negara. Selain itu keluarga merupakan lingkungan pendidikan pertama bagi diri setiap anak. Penanaman nilai karakter dan moralitas seseorang, salah satunya terbentuk dari pengaruh lingkungan keluarganya. Tugas utama dari keluarga bagi pendidikan anak ialah sebagai pelekat dasar bagi pendidikan akhlak sebab sifat dan tabiat anak sebagaian besar mempengaruhi seseorang dalam melakukan kejahatan seperti tindak pidana asusila terutama tindak pidana pencabulan. Namun kenyataan yang terjadi dalam lingkungan keluarga pun dijumpai kasus-kasus pencabulan terhadap anak. Yang paling rawan menjadi korban pencabulan ialah anak perempuan, anak perempuan yang kadang menjadi korban dari tindakan bejat ayahnya sendiri.

2.3. Faktor lingkungan masyarakat

Pembentukan terhadap kepribadian dan perilaku seseorang banyak dipengaruhi oleh keadaan lingkungan sekitarnya. Kejahatan asusila merupakan tindakan manusia terhadap manusia lainnya di dalam masyarakat. Oleh karena itu manusia adalah anggota dari masyarakat, maka kejahatan asusila tidak dapat dipisahkan dari masyarakat. Mencuatnya perilaku negatif anak dipicu oleh faktor lingkungan anak.

2.4. Pemahaman agama yang minim

Agama merupakan unsur pokok dan utama dalam kehidupan manusia yang didalamnya menganjurkan dan membimbing setiap umat manusia untuk berbuat kebaikan dan menghindari kejahatan. Agama juga mengajarkan hal-hal yang boleh dan tidak boleh dilakukan karena bisa merugikan orang lain atau diri sendiri. Agama juga tentu saja melarang seseorang melakukan kejahatan karena hal itu dianggap sebagai dosa besar. Biasanya pelaku melakukan kejahatan terlarang tersebut karena tingkat keimanan dan kepercayaan pelaku terhadap TuhanYME kurang sehingga tidak bisa membentengi dirinya terhadap perbuatan dosa.

2.5. Ketidakpahaman akan persoalan seksualitas

Pemahaman tentang seks diberikan pada seorang anak secara bertahap, sesuai dengan usia seorang anak. Beragam kasus seksual salah satunya tindak pidana pencabulan terhadap anak terjadi yang menimpa kanak-kanak, disebabkan karena ketidakpahaman anak akan persoalan seksualitas sehingga mereka dengan mudahnya diperalat oleh pelaku dalam melancarkan aksinya. 


\section{B. Sanski Hukum terhadap pelaku tindak pidana pencabulan terhadap anak menurut ketentuan Undang-Undang Perlindungan Anak}

Hukum positif di Indonesia saat ini memang sudah mengatur secara khusus hukum yang mengatur tentang pasal-pasal yang dikenakan bagi pelaku tindak pidana pencabulan terhadap anak dibawah umur. Hukum yang ada dan diterapkan bagi si pelaku adalah sebagai bentuk perlindungan bagi korban dan mencegah perbuatan dilakukan kembali atau memberi efek jera bagi pelaku.

Ketentuan yang mengatur mengenai tindak pidana pencabulan sendiri dalam Kitab Undang-Undang Hukum Pidana pada Bab XIV buku ke II, yaitu pada Pasal 289 sampai dengan Pasal 29 Kitab Undang-Undang Hukum Pidana, pencabulan tersebut dikategorikan sebagai kejahatan terhadap kesusilaan. Sedangkan pencabulan terhadap anak diatur dalam Pasal 290 ayat (2) dan ayat (3), Pasal 292, Pasal 293, Pasal 294 ayat (1) dan Pasal 295 Kitab Undang-Undang Hukum Pidana. Serta diatur juga di dalam Pasal 76 E dan Pasal 82 Undang-Undang Nomor 35 Tahun 2014 tentang Perlindungan Anak.

Ketentuan hukum tindak pidana pencabulan anak terhadap anak yang tertuang dalam Undang-Undang Nomor 35 Tahun 2014 tentang Perubahan atas Undang-Undang Nomor Nomor 23 tahun 2002 tentang Perlindungan Anak, disebutkan dalam Pasal 76 E dan Pasal 82.

- Pasal 76 : "setiap orang dilarang melakukan kekerasan atau ancaman kekerasan, memaksa, melakukan tipu muslihat, melakukan serangkaian kebohongan, atau membujuk anak untuk melakukan atau membiarkan dilakukan perbuatan cabul".

- Pasal 82

ayat (1) : "setiap orang yang melanggar ketentuan sebagaimana dimaksud dalam Pasal 76 E di pidana dengan pidana penjara paling singkat 5 tahun dan paling lama 15 tahun dana denda paling banyak Rp. 5.000.000.000,-00 (lima miliyar rupiah)"

ayat (2): "dalam hal tindak pidana sebagaimana dimaksud pada ayat (1) dilakukan oleh orang tua, wali, pengasuh anak, pendidik atau tenaga kependidikan, maka pidananya ditambah $1 / 3$ (sepertiga) dari ancaman pidana sebagaimana dimaksud pada ayat (1)".

Jika diuraikan, maka unsur-unsur tindak pidana pada Pasal 76 E Undang-Undang Nomor 35 Tahun 2014 tentang Perlindungan Anak, yaitu sebagai berikut :

a. Setiap orang

Merupakan unsur subjektif yang berarti adanya pelaku (orang yang 
dapat bertanggung jawab) yang melakukan perbuatan yang dapat dipidana sesuai dengan pasal ini.

b. Dengan sengaja

Merupakan unsur subjektif yang berasal dari dalam diri si pelaku, yang mana si pelaku telah melakukannya secara sadar, mengerti dan benar-benar menghendaki perbuatan yang ia lakukan.

c. Melakukan kekerasan atau ancaman kekerasan, memaksa, melakukan tipu muslihat, serangkaian kebohongan atau membujuk anak

Pada dasarnya unsur ini memiliki kemiripan dengan unsur yang disebutkan dalam Pasal 290 ayat (3) Kitab Undang-Undang Hukum Pidana yakni adanya tindakan kekerasan, paksaan, serangkaian kebohongan, tipu muslihat dan bujukan yang dilakukan kepada anak dengan maksud agar si anak melakukan sesuatu yang dikehendaki oleh si penipu.

d. Untuk melakukan atau membiarkan melakukan perbuatan cabul

Ini merupakan unsur terakhir yang merupakan tujuan utama dari sipelaku.

Adanya Undang-Undang Nomor 35 Tahun 2014 tentang Perlindungan Anak tentu memberikakn angin sgar bagi masyarakat Indonesia, karena dalam undang-undang ini memberikan sanski-sanski yang lebih berat bagi pelaku pencabulan anak. Sanski yang cukup berat tersebut diharapkan dapat memberikan efek jera bagi pelaku.

\section{PENUTUP}

\section{A. Kesimpulan}

1. Secara garis besar faktor penyebab terjadinya tindak pidana pencabulan terhadap anak dibawah umur yaitu, yang pertama adalah disebabkan oleh faktor dalam diri sipelaku itu sendiri sehingga ia melakukan perbuatan cabul. Karena faktor penyebab dalam diri yang berkaitan dengan faktor kejiwaan dan psikis pelaku dan yang kedua adalah disebabkan oleh faktor dari luar diri pelaku yaitu :

- faktor rendahnya pendidikan dan ekonomi;

- faktor lingkungan keluarga;

- faktor lingkungan masyarakat;

- pemahaman agama yang minim;

- ketidakpahaman akan persoalan seksualitas.

2. Ketentuan hukum tindak pidana pencabulan anak terhadap anak yang tertuang dalam Undang-Undang Nomor 35 Tahun 2014 tentang Perubahan atas Undang-Undang Nomor Nomor 23 tahun 2002 tentang Perlindungan Anak, disebutkan dalam Pasal 76 E dan Pasal 82. 
Dalam Pasal 82 Undang-Undang Nomor 35 Tahun 2014, menyebutkan Sanski hukum yang diberikan terhadap pelaku tindak pidana perbuatan cabul yaitu pidana penjara paling sedikit lima tahun dan paling banyak lima belas tahun dan denda paling banyak lima miliyar rupiah, sedangkan bila pelakunya adalah orang tuanya, wali, pengasuh anak, guru (pendidik) maka sanski pidananya ditambah sepertiga dari ancaman tersebut diatas.

\section{B. Saran}

1. Perlu adanya peningkatan mentalitas, moralitas serta keimanan dan ketaqwaan bagi masyarakat hal ini diharapkan bertujuan untuk dapat pengendalian diri yang kuat, terpuji dan dapat mencegah pikiran dan niat jahat. Diharapkan juga agar masyarakat selalu berusaha semaksimal mungkin mengisi hari-hari dengan kegiatan yang bersifat positif dan menjaga sopan santun dalam bertingkah laku dan berbusana yang baik.

2. Perlu adanya pemberian konseling bagi korban kejahatan pencabulan, pemberian konseling bagi korban kejahatan pencabulan yang mengalami trauma berkepanjangan sebagai upaya rehabilitasi. Hal ini sangat bermanfaat bagi korban pencabulan untuk mengembalikan kepercayaan dirinya. Kegiatan konseling dapat dilakukan oleh pemerintah maupun lembaga swadaya masyarakat yang berfokus kepada masalah perlindungan anak juga dibantu oleh keluarga korban. Dan dapat juga diberikan bantuan hukum berupa advokasi dan pendampingan kepada korban hal ini telah dilakukan oleh YLBH Apik Kaltim yang telah banyak mendampingi korban kejahatan terhadap anak dan perempuan. Dan aparat penegak hukum harus tegas dalam memberikan sanski kepada pelaku tindak pidana pencabulan.

\section{DAFTAR PUSTAKA}

\section{A. Buku Bacaan}

Abdul Wahid dan Muhammad Irfab, 2001, Perlindungan Terhadap Korban Kekerasan Seksual (Advokasi atas Hak Asasi Perempuan). Refika, Bandung

Abdullah dab Sitompul, 2007, Sistem Peradilan Pidana, Restu Agung, Jakarta

Abintoro Prakoso, 2016, Hukum Perlindungan Anak, LaksBang PRESSindo, yogyakarta 
Adami Chazawi, 2007, Tindak Pidana Mengenai Kesopanan, Penerbit Rajawali Grafindo Persada, Jakarta.

Amir Ilyas, 2012, Asas-asas Hukum Pidana, Penerbit Rangkang Education Yogyakarta, Yogyakarta.

Arif Gosita, 1993, Masalah Korban Kejahatan, CV. Akademika Persada, Jakarta.

A.S. Alam, 2010, Pengantar Kriminologi, Pustaka Refleksi, Makasar

Laden Marpaung, 2008, Asas-asas-Praktik Hukum Pidana, Penerbit Sinar Grafika, Jakarta.

Muladi dan Barda Nawawi Arif, 1998, Teori-teori dan Kejahatan Pidana, Alumni, Bandung

Moeljatno, 1993, Asas-asas Hukum Pidana, Rineka Cipta, Jakarta

P.A.F Lamintang, 1997, Dasar-dasar Hukum Pidana Indonesia, Penerbit Citra Aditya Bakti, Bandung

R.A. Koesnan, 2005, Susunan Pidana Dalam Negara Sosialis, Sumur, Bandung.

Sudaryono dan Natangsa Subakti, 2005, Hukum Pidana, Penerbit Fakultas Hukum Muhamadiyah Surakarta, Surakarta.

Teguh Prasetyo, 2015 Hukum Pidana, Cetakakn ke -VI, Penerbit PT Raja Grafindo Persada, Jakarta.

Tongat, 2009, Dasar-dasar Hukum Indonesia Dalam Perspektif Pembaharuan, UMM Malang

Wirjono Projodikoro, 1981, Asas-asas Hukum Pidana di Indonesia, Cet. Ke III, penerbit Eresco.

Yanti Yuniar, 2012, Kamus Lengkap Bahasa Indonesia, Penerbit Agung Mulia, Jakarta.

Zakariya Ahmad Al Barry, 1993, Hukum Anak Dalam Islam, Bulan Bitang, Jakarta

\section{B. Peraturan Perundang-undangan}

Undang-Undang Dasar Negara Republik Indonesia Tahun 1945

Kitab Undang-Undang Hukum Pidana

Undang-Undang Nomor 4 Tahun 1974 tentang Kesejahteraan Anak 
Jurnal LEGALITAS Volume 5 Nomor 2, Desember 2020 ISSN CETAK $\quad$ 2597-968X ISSN ONLINE 2548-8244

Undang-Undang Nomor 39 Tahun 1999 tentang Hak Asasi Manusia Undang-Undang Nomor 2 Tahun 2002 tentang Perlindungan Anak

Undang-Undang Nomor 11 Tahun 2012 tentang Sistem Peradilan Pidana Anak

Undang-Undang Nomor 35 tahun 2014 tentang Perubahan atas Undang-Undang Nomor 2 tahun 2002 tentang Perlindungan Anak

\section{Website}

id.m.wikipedia.org 